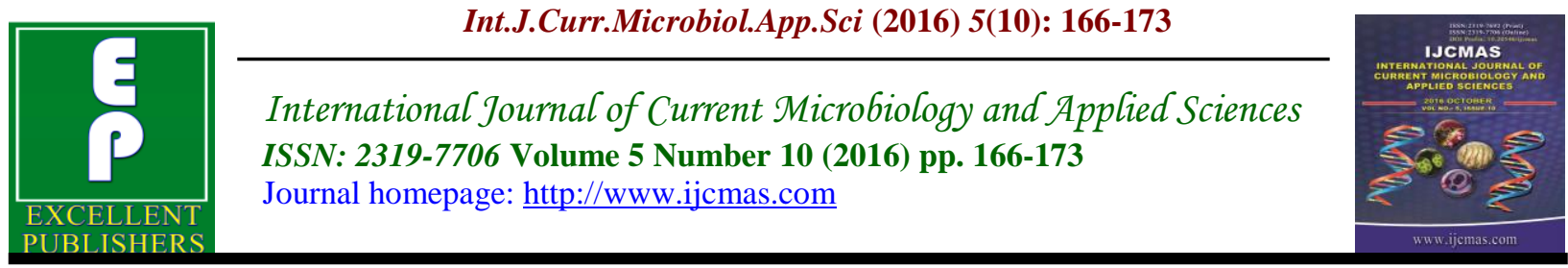

Original Research Article

http://dx.doi.org/10.20546/ijcmas.2016.510.019

\title{
Ground Water Quality Assessment of Ramgarh Mod in Jaipur City, India
}

\author{
Surendra Kumar Sharma ${ }^{1}$, Richa Sharma ${ }^{1 *}$, Manisha Mathur ${ }^{1}$ and C.P.S. Chandel ${ }^{2}$ \\ ${ }^{1}$ Department of Chemistry, S.S. Jain Subodh P G (Autonomous) College, Jaipur, India \\ ${ }^{2}$ Department of Chemistry, University of Rajasthan, Jaipur, India \\ *Corresponding author
}

\begin{tabular}{|c|c|}
\hline & A B S T R A C T \\
\hline $\begin{array}{l}\text { Ground water, } \\
\text { water pollution, } \\
\text { water quality, } \\
\text { Trace metals, } \\
\text { WHO standards. }\end{array}$ & \multirow{3}{*}{$\begin{array}{l}\text { Water pollution in India a major problem, the management of which } \\
\text { requires continuous monitoring and the effective implementation of water } \\
\text { resource policy at all levels. The objective of the present study is to evaluate } \\
\text { the water quality of Ram Garhmoad which also forms the catchment of the } \\
\text { JalMahal. Results were compared with standards as prescribed by ISI, and } \\
\text { WHO. Ground water samples from hand pump and tubewell of Ram } \\
\text { GarhMoad analyzed throughout the two years during all three sessions from } \\
\text { June } 2013 \text { to May } 2015 \text { with the help of standard methods of APHA. The } \\
\text { concentration of pH, } \mathrm{Na}^{+}, \mathrm{K}^{+}, \mathrm{Mg}^{2+}, \mathrm{SO}_{4}{ }^{2-}, \mathrm{CO}_{3}{ }^{2-}, \mathrm{HCO}_{3}{ }^{2-}, \mathrm{Cl}^{-}, \mathrm{DO}, \mathrm{BOD} \\
\text { and COD were within permissible limits but } \mathrm{NO}_{3}{ }^{-}, \mathrm{EC}, \mathrm{TDS}, \mathrm{TH} \text { and WQI } \\
\text { values showed the poor water quality. }\end{array}$} \\
\hline Article Info & \\
\hline $\begin{array}{l}\text { Accepted: } \\
\text { 12 September } 2016 \\
\text { Available Online: } \\
10 \text { October } 2016\end{array}$ & \\
\hline
\end{tabular}

\section{Introduction}

Water is a source of life and regarded as the most essential of natural resources. Water covers approximately $98 \%$ is seawater and is unusable for drinking because of the high concentration of salt. About $2 \%$ of the planet,s water is fresh, but $1.6 \%$ is locked up in polar ice caps and glaciers. Another $0.36 \%$ is found under ground in aquifers and wells (Adak and Purohit, 2001).

Rajasthan is India's largest state with an area of 3.42 lakh sq.kms, which is $10.41 \%$ of the country's area; and estimated population of 54 million spread over its 41,583 villages, which is $5.5 \%$ of nation's population but has just $1 \%$ of the total water sources of the country. In most of the parts of the state, groundwater is either saline or has excess fluoride. Groundwater is the major source of drinking water and over $91 \%$ of the drinking water demand is met by groundwater. So, due to scarcity of the surface water in Rajasthan, $70 \%$ of its population is dependent on groundwater resources for drinking, irrigation and other purposes (Bruvold, 1967; Almeida, et al., 2008; Berkowitz, et al., 2008).

\section{Materials and Methods}

Ground water samples were collected from different sites from the flanking localities of 
Ram Garh Moadin Jaipur city. Samples were collected in sterilized screw-capped polyethylene bottles of one litre capacity, labeled properly and analyzed in laboratory for their all physic-chemical parameters. Monitoring was done through the two years in all three session from June,2013 to May, 2015. The instruments were used in the limit of precise accuracy, chemicals used were of Analytical grade and double distilled water was used for preparing solutions for analysis. Collected water samples were determined as per standard methods, APHA (1995) (Dalton, M.G., and Upchurch, 1978; Dar and Sankar, 2011). The suitability of the ground water for drinking purpose was evaluated by using WQI and other parameters. Various physical parameters like $\mathrm{pH}, \mathrm{EC}, \mathrm{DO}$ and TDS, were determined on the site with the help of digital portable water analyzer kit (CENTURY-CK-710) or by $\mathrm{pH}-$ meter (Mettler Toledo). For rest of the analysis, water samples were preserved and bought to the laboratory. The chemical analysis carried out for BOD by incubation method, COD by $\mathrm{KMnO}_{4}$ method, Calcium $\left(\mathrm{Ca}^{2+}\right)$, Magnesium $\left(\mathrm{Mg}^{2+}\right)$, Chloride $\left(\mathrm{Cl}^{-}\right)$, Sulphate $\left(\mathrm{SO}_{4}{ }^{2-}\right)$, Carbonate $\left(\mathrm{CO}_{3}{ }^{2-}\right)$ and Bicarbonate $\left(\mathrm{HCO}_{3}{ }^{-}\right)$by volumetric titration methods; while Fluoride $\left(\mathrm{F}^{-}\right)$by spectrophotometric (AIMIL-C160-80314) $\&$ ion selective electrode method and Nitrate $\left(\mathrm{NO}_{3}{ }^{-}\right)$by spectrophotometric (ELICO-CL54D) method; Sodium $\left(\mathrm{Na}^{+}\right)$, Potassium $\left(\mathrm{K}^{+}\right)$by flamephotometry (ELICO-CL-220) and heavy metals by AAS.

\section{Evaluation of Water Quality for Drinking Purpose}

To determine the suitability of water for drinking purpose, an indexing system, Water Quality Index (WQI), based on Adak and Purohit (2001) was determined. Water Quality Index can be calculated from the following formula ${ }^{1}$

$\mathrm{WQI}=\operatorname{Antilog}\left(\Sigma \mathrm{W}_{\mathrm{n}} \log \mathrm{Q}_{\mathrm{n}}\right)$ where:

$\mathrm{W}$ (Weight of the Pollutants in the Sample) $=\mathrm{K} / \mathrm{S}_{\mathrm{n}}$

$\mathrm{K}($ constant $)=1 /\left(1 / \mathrm{S}_{1}+1 / \mathrm{S}_{2}+1 / \mathrm{S}_{3}+\ldots \ldots \ldots\right.$ $\left.+1 / S_{n}\right)$

$\mathrm{S}_{\mathrm{n}}=$ Standard Values for Different Water Quality Parameters

$\mathrm{Q}_{\mathrm{n}}$ (Water Quality Rating) $=100\left(\mathrm{~V}_{\mathrm{n}}-\mathrm{V}_{1}\right) /$ $\left(\mathrm{S}_{\mathrm{n}}-\mathrm{V}_{1}\right)$

$\mathrm{V}_{\mathrm{n}}=$ Observed Values

$\mathrm{V}_{1}$ (Ideal Values $)=7.0$ for $\mathrm{pH}$ and 0 for all other parameters

\section{Results and Discussion}

Water samples of Ram GarhMoad (SA) were collected and analyzed as per standard methods and the water quality index (WQI) was determined. With the help of WQI, we assessed the seasonal results of Ram GarhMoad. Sampling was done during three seasons (during monsoon, post-monsoon and pre-monsoon) throughout the two-years from various areas vicinal to Amanishanalla during (June, 2013 to May, 2015). Results of three season's physico-chemical analysis are shown in Table IA and Table IB. Heavy metal analysis are shown in Table 2A. Suitability of ground water for domestic and irrigation purposes are classified on the basis of Piper diagram (Figure 1) and USSL diagram (Figure 2).

Electrical Conductivity (EC): The physico-chemical data reveals that the EC values varied from 1800 to 2836 $\mu$ seimens/cm and these values were much higher than the prescribed standard limit (1400 $\mu$ seimens/cm) recommended by WHO for all the samples analyzed during 
2013 - 2015.The minimum and maximum values of EC were observed in sample SA 6 and SA 5 respectively.

pH: $\mathrm{pH}$ values ranged 7.84 to 8.22 during two years samplings with an average value of 7.99. $\mathrm{pH}$ values showed that water samples were slightly alkaline in nature and these values were within the limit as prescribed by WHO for all samples. The minimum and maximum value of $\mathrm{pH}$ was monitored in sample SA2 and SA5 respectively.

Calcium $\left(\mathrm{Ca}^{2+}\right)$ : Calcium values were varied from 127.0 to $211.00 \mathrm{mg} / \mathrm{L}$ and these values were within the permissible limit prescribed by ICMR \& BIS except SA3. The average value of calcium was $167.00 \mathrm{mg} / \mathrm{L}$. In sample SA6 minimum value of calcium was observed and in sample SA3, maximum value was surveyed.

Magnesium $\left(\mathrm{Mg}^{2+}\right)$ : The data table reveals that the magnesium values varied from 82.82 to $122.95 \mathrm{mg} / \mathrm{L}$. All groundwater samples were within the standard limit recommended by WHO. The minimum and maximum value of magnesium was observed in sample SA2 and SA4 respectively. $98.02 \mathrm{mg} / \mathrm{L}$ was the average value of magnesium.

Sodium $\left(\mathrm{Na}^{+}\right)$: Sodium values ranged from 128 to $233 \mathrm{mg} / \mathrm{L}$ with an average value of $191.00 \mathrm{mg} / \mathrm{L}$ for all of the studied samples. SA1, SA2 AND SA4 were higher values than the prescribed US standards. The minimum value of sodium was examined in sample SA6 and the maximum value of sodium was examined in sample SA4.

Potassium $\left(\mathrm{K}^{+}\right)$: Potassium values ranged from 6.2 to $26 \mathrm{mg} / \mathrm{L}$ and the average value of potassium was $15.16 \mathrm{mg} / \mathrm{L}$. The minimum value of potassium was examined in sample SA6 and the maximum value of Potassium was scrutinized in sample SA1.

Carbonate $\left(\mathrm{CO}_{3}{ }^{2-}\right)$ and Bicarbonate $\left(\mathrm{HCO}_{3}{ }^{-}\right)$: Carbonate concentration in the study area ranged from nil to $14 \mathrm{mg} / \mathrm{L}$ and the average value of carbonate was $4 \mathrm{mg} / \mathrm{L}$. Bicarbonate values were varied from 172.0 to $508.0 \mathrm{mg} / \mathrm{L}$ and all bicarbonate values were within permissible limit prescribed by USPH except SA4. The average value of bicarbonate was $272.00 \mathrm{mg} / \mathrm{L}$. In sample SA2 minimum value of bicarbonate was observed and in sample SA4 maximum value was surveyed.

Chloride $\left(\mathrm{Cl}^{-}\right)$: Chloride values ranged from 307.88 to $637.25 \mathrm{mg} / \mathrm{L}$ with an average value of $481.10 \mathrm{mg} / \mathrm{L}$. All samples were exceeding values than the prescribed WHO and US standards. The minimum value of chloride was examined in sample SA6 and the maximum value of chloride was scrutinized in SA1.

Sulphate $\left(\mathrm{SO}_{4}{ }^{2-}\right)$ :Sulphate values ranged 106 to $208 \mathrm{mg} / \mathrm{L}$ during two years samplings. All these values were within the limit as prescribed by WHO for all studied samples. The average value of sulphate was $139.00 \mathrm{mg} / \mathrm{L}$. Sulphate was monitored in sample SA2 as minimum value and sulphate was monitored in sample SA4 as maximum value.

Nitrate $\left(\mathrm{NO}_{3}{ }^{-}\right)$: Nitrate values ranged from 182 to $250 \mathrm{mg} / \mathrm{L}$ with an average value of $209 \mathrm{mg} / \mathrm{L}$ for all of the studied samples of both years. All samples were above as prescribed by WHO, US Standard, BIS and ICMR. The minimum value of nitrate was examined in sample SA2 and the maximum value of nitrate was scrutinized in SA6.

Fluoride $\left(\mathbf{F}^{-}\right)$: Fluoride values in both years varied from 1.0 to $1.3 \mathrm{mg} / \mathrm{L}$ with an average value of $0.83 \mathrm{mg} / \mathrm{L}$. Most of the 
groundwater samples were below the standard limit recommended by ICMR.The minimum value of fluoride was observed in samples SA1 and the maximum value of fluoride was found in sample SA6.

Total Hardness (TH): $\mathrm{TH}$ values varied from 635.00 to $940.00 \mathrm{mg} / \mathrm{L}$. The minimum value of TH was found in sample SA6 and the maximum value of $\mathrm{TH}$ was detected in sample SA3. The average value of $\mathrm{TH}$ was $788.00 \mathrm{mg} / \mathrm{L}$. All samples were above the value recommended by WHO standards in both years.

Total Dissolved Solids (TDS): TDS values were varied from 1070.00 to $1611.00 \mathrm{mg} / \mathrm{L}$ and these all values were above the permissible limit prescribed by ICMR \& WHO. The average value of TDS was $1442.00 \mathrm{mg} / \mathrm{L}$. In sample SA6 minimum value of TDS was observed and in sample SA1 maximum value was surveyed.

Dissolved Oxygen (DO): DO values varied from 4.93 to $7.3 \mathrm{mg} / \mathrm{L}$ with an average value of $6.27 \mathrm{mg} / \mathrm{L}$. There were not any large variations of DO values found and 33\% samples were within the limit recommended by USPH standards. The minimum and maximum value of DO was observed in sample SA6 and SA4.

\section{Biochemical Oxygen Demand (BOD):} BOD values ranged 1.09 to $10.9 \mathrm{mg} / \mathrm{L}$ and all these values were within the limit as prescribed by USPH for all studied samples except SA3 and SA5. The average value of BOD was $5.02 \mathrm{mg} / \mathrm{L}$. BOD was monitored in sample SA6 as minimum and in sample SA5 as maximum value.

Chemical Oxygen Demand (COD): COD values were varied from 2.5 to $24 \mathrm{mg} / \mathrm{L}$ and all these values were not within permissible limit prescribed by USPH standards except SA6. The average value of COD was 9.55 $\mathrm{mg} / \mathrm{L}$. In sample SA6 minimum value of COD was observed and in sample SA5 maximum value was surveyed.

Percent Sodium (\% Na): All values of $\% \mathrm{Na}$ were under recommended CPCB standards in both years. $\% \mathrm{Na}$ values varied from 30.22 to 38.88 . The minimum value of $\% \mathrm{Na}$ was found in sample GB6 and the maximum value of $\% \mathrm{Na}$ was detected in sample SA4.

Sodium Absorption Ratio (SAR): SAR values ranged from 2.12 to $3.41 \mathrm{meq} / \mathrm{L}$ with an average value of SAR was $2.86 \mathrm{meq} / \mathrm{L}$ all of the studied samples of two years analysis. All samples were lesser values than the prescribed CPCB standards and the minimum and maximum values of SAR were scrutinized in samples SA6 \& SA4. Data is plotted on the US salinity diagram (Figure 2), in which EC is taken as salinity hazard and SAR is taken as alkalinity hazard. Most of the ground water samples fall in the C4S1 category with very high salinity hazard and low sodium hazard, which is not suitable for irrigation under ordinary conditions but may be used occasionally under special circumferences. One sample SA6 fall in C3S1 quality with high salinity hazard and low sodium hazard, which can be used for irrigation on almost all type of soil with little danger of exchangeable sodium.

Residual Sodium Carbonate (RSC): All RSC values were found negative and these values are suitable ${ }^{23}$ for irrigation purpose.

Water Quality Index (WQI): The critical study from the WQI Table reveals that WQI values of two years were varied from 40.57 to 89.07 with an average value 58.54 , which means that all water of samples were of very good to good quality except SA5. It may be concluded with the help of WQI that the water of the various samples were fit for drinking purpose except one case. 
Heavy Metals: from the Table 2A, it is reveal that heavy metals like $\mathrm{Co}, \mathrm{Cd}, \mathrm{Pb}$ and $\mathrm{Mn}$ values non-detectable (ND). $\mathrm{Cu}, \mathrm{Fe}$ and $\mathrm{Zn}$ values were found within the permissible limit prescribed by BIS.

Piper Trilinear Diagram: Major cations and anions such as $\mathrm{Ca}^{2+}, \mathrm{Mg}^{2+}, \mathrm{Na}^{+}, \mathrm{K}^{+}$, $\mathrm{CO}_{3}{ }^{2-}, \mathrm{HCO}_{3}{ }^{-}, \mathrm{SO}_{4}{ }^{2-}$ and $\mathrm{Cl}^{-}$in meq/L were plotted in Piper's trilinear diagram ${ }^{77}$ to evaluate the hydrochemistry of groundwater with the help of GWW- software (Figure 1). On the basis of Walton's classification ${ }^{146}$, all the water samples showed an excess of alkaline earth $\left(\mathrm{Ca}^{2+}+\mathrm{Mg}^{2+}\right)$ over alkalies $\left(\mathrm{Na}^{+}+\mathrm{K}^{+}\right)$and all the groundwater samples showed an excess of strong acids $\left(\mathrm{SO}_{4}{ }^{2-}+\right.$ $\left.\mathrm{Cl}^{-}\right)$over weak acids $\left(\mathrm{CO}_{3}{ }^{2-}, \mathrm{HCO}_{3}{ }^{-}\right)$. The plot shows that most of the groundwater samples fall in the field of mixed type water (No cation - anion exceed 50\%).

Table.1a Physico- Chemical Parameters of Groundwater of Ram

GarhMoad during 2013 to 2015

\begin{tabular}{|l|l|c|c|c|c|c|c|c|c|c|c|c|c|}
\hline CODE & \multicolumn{1}{|c|}{ Season } & $\mathbf{E C}$ & $\mathbf{P h}$ & $\mathbf{C a}^{2+}$ & $\mathbf{M g}^{2+}$ & $\mathbf{N a}^{+}$ & $\mathbf{K}^{+}$ & $\mathbf{C O}_{3}{ }^{2-}$ & $\mathbf{H C O}_{3}^{-}$ & $\mathbf{C l}^{-}$ & $\mathbf{S O}_{4}{ }^{-2}$ & $\mathbf{N O}_{\mathbf{3}}^{-}$ & $\mathbf{F}^{-}$ \\
\hline S A1 & MONSOON 13 & 2777 & 7.85 & 203.39 & 97.42 & 210 & 26 & 2 & 209.4 & 637.25 & 120 & 210 & 0.7 \\
\hline SA2 & POSTMONSOON 13-14 & 2452 & 7.84 & 171.33 & 82.82 & 214 & 14 & 2 & 172.8 & 572.27 & 106 & 190 & 0.71 \\
\hline SA3 & PREMONSOON 14 & 2710 & 7.92 & 211.41 & 105.93 & 192 & 20 & 14 & 227.7 & 604.76 & 129 & 208 & 0.74 \\
\hline SA4 & MONSOON 14 & 2738 & 7.94 & 145.47 & 122.95 & 233 & 18 & 2 & 508.3 & 322.17 & 208 & 214 & 0.71 \\
\hline SA5 & POSTMONSO0ON 14-15 & 2836 & 8.22 & 145.28 & 96.2 & 170 & 6.8 & 2 & 282.6 & 442.32 & 160 & 250 & 0.85 \\
\hline SA6 & PREMONSOON 15 & 1800 & 8.20 & 127.25 & 82.82 & 128 & 6.2 & 2 & 233.8 & 307.88 & 116 & 182 & 1.3 \\
\hline
\end{tabular}

Table.1b Physico- Chemical Parameters of Groundwater of Ram

GarhMoad during 2013 to 2015

\begin{tabular}{|c|l|c|c|c|c|c|c|c|c|c|}
\hline CODE & \multicolumn{1}{|c|}{ Season } & DO & BOD & COD & TH & TDS & \% Na & SAR & RSC & WQI \\
\hline SA1 & MONSOON 13 & 6.92 & 1.7 & 4.85 & 885.68 & 1566 & 35.15 & 2.99 & -14.1 & 40.57 \\
\hline SA2 & POSTMONSOON 13-14 & 6.71 & 3.6 & 8 & 745.55 & 1394 & 38.88 & 3.33 & -11.89 & 49.28 \\
\hline SA3 & PREMONSOON 14 & 5.26 & 9.54 & 8 & 940.73 & 1554 & 31.49 & 2.65 & -14.50 & 58.43 \\
\hline SA4 & MONSOON 14 & 7.3 & 3.3 & 10 & 846.11 & 1475 & 38.096 & 3.41 & -8.40 & 51.95 \\
\hline SA5 & POSTMONSOON 14-15 & 6.5 & 10.9 & 24 & 735.56 & 1369 & 33.352 & 2.64 & -9.9 & 89.075 \\
\hline SA6 & PREMONSOON 15 & 4.93 & 1.09 & 2.5 & 635.48 & 1025 & 30.22 & 2.12 & -8.69 & 61.92 \\
\hline
\end{tabular}


Table.2a Heavy Metals Concentration of Groundwater of RamGarhMoad

\begin{tabular}{|c|c|c|c|c|c|c|c|c|}
\hline Sample Code & Season & Co & Cd & $\mathbf{C u}$ & $\mathbf{F e}$ & $\mathbf{M n}$ & $\mathbf{P b}$ & $\mathbf{Z n}$ \\
\hline SA 1 & MONSOON 13 & ND & ND & 0.02 & 0.03 & ND & ND & 0.06 \\
\hline SA 2 & $\begin{array}{l}\text { POST MON 13- } \\
14\end{array}$ & ND & ND & 0.08 & 0.06 & ND & ND & 1.1 \\
\hline SA 3 & PRE MON 14 & ND & ND & 0.04 & 0.02 & ND & ND & 0.02 \\
\hline SA 4 & MONSOON 14 & ND & ND & 0.01 & 0.01 & ND & ND & 0.06 \\
\hline SA 5 & $\begin{array}{c}\text { POST MON 14- } \\
15\end{array}$ & ND & ND & 0.01 & 0.04 & ND & ND & 0.08 \\
\hline SA 6 & PRE MON 15 & ND & ND & 0.02 & 0.02 & ND & ND & 0.8 \\
\hline
\end{tabular}

Fig.1 Groundwater quality of sample SA on the basis of Piper Diagram

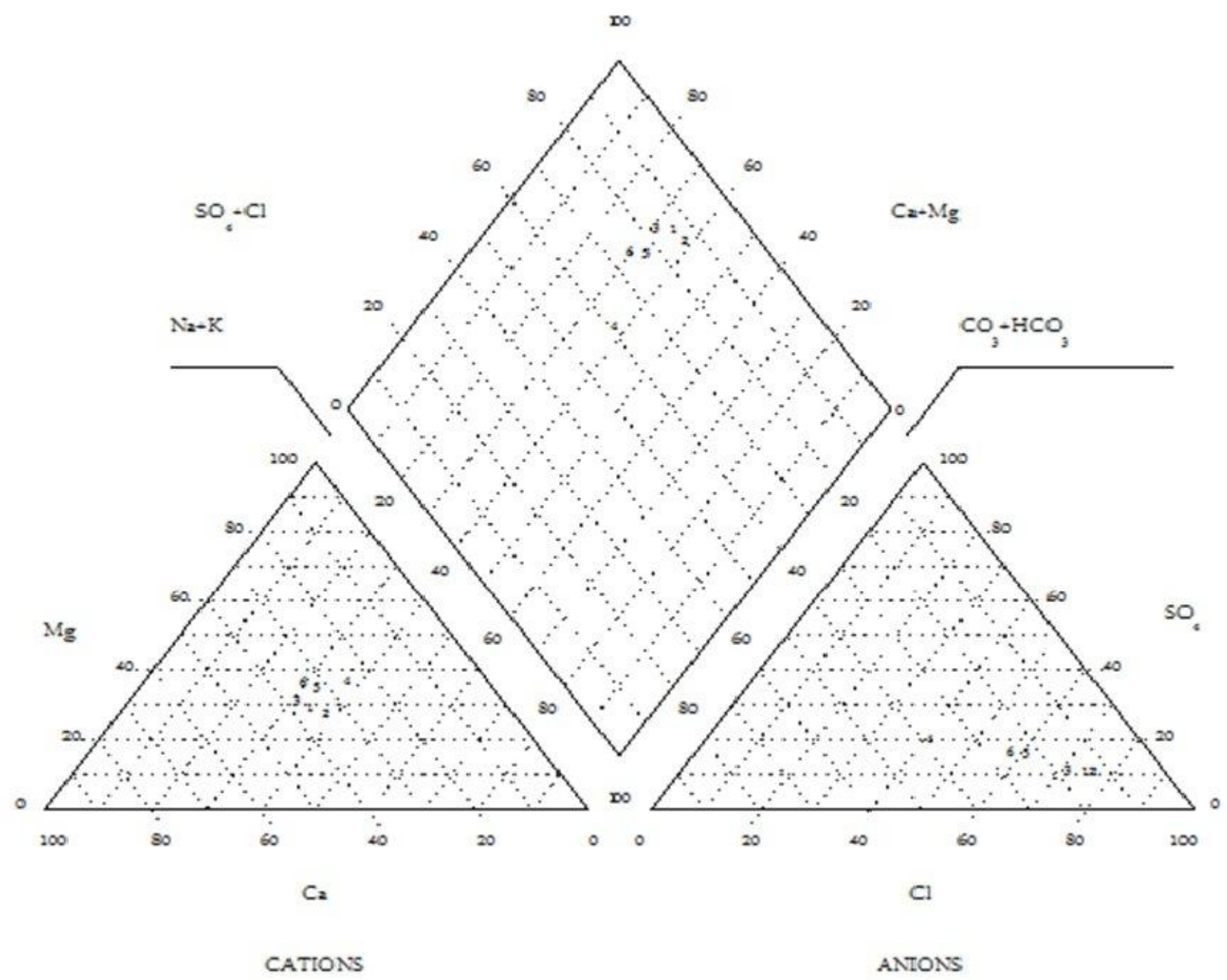


Fig.2 Groundwater quality of sample SA on the basis of USSL Diagram

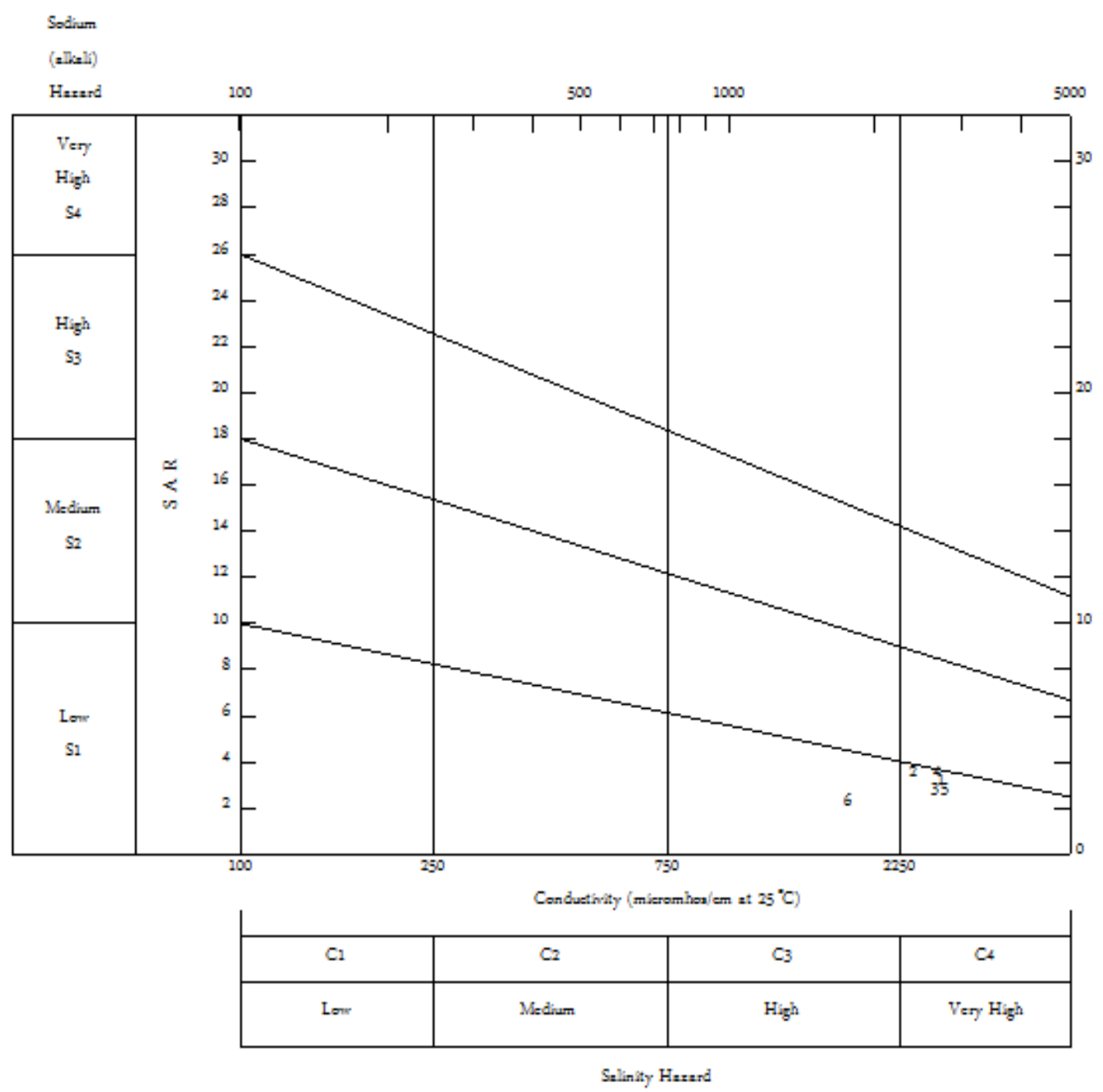

In conclusion, almost all results reveal that most of the water samples were alkaline in nature. The values obtained were compared with standards of BIS, ICMR, USPH and WHO. From the observations, it may inferred that the concentration of $\mathrm{pH}, \mathrm{Na}^{+}$, $\mathrm{K}^{+}, \mathrm{Mg}^{2+}, \mathrm{SO}_{4}{ }^{2-}, \mathrm{CO}_{3}{ }^{2-}, \mathrm{HCO}_{3}{ }^{2-}, \mathrm{Cl}^{-}, \mathrm{DO}$, $\mathrm{BOD}$ and $\mathrm{COD}$ were within permissible limits but $\mathrm{NO}_{3}{ }^{-}, \mathrm{EC}, \mathrm{TDS}, \mathrm{TH}$ and WQI values showed the poor water quality in most of the studied groundwater samples .

It may be accomplished with the help of WQI that the water of the various samples were unfit for drinking purpose without further treatment (mainly disinfections).
It may be concluded that the from the Piper trilinear diagram that the ground water from sampling stations are mixed type water type and $\mathrm{Ca}-\mathrm{Mg}-\mathrm{HCO}_{3}$ type. The values of SAR and $\mathrm{EC}$ of the ground water were plotted in the US salinity laboratory diagram for irrigation water. Most of the samples fall in C3S1 quality with high salinity hazard and low sodium hazard. In most of the samples, RSC values were found below the zero, which means waters containing a carbonate plus bicarbonate concentration greater than the calcium plus magnesium concentration and these values fall in under "good" category. RSC and \% $\mathrm{Na}$ values indicate that the samples were good for irrigation 
purpose. Concentrations of all heavy metals like $\mathrm{Cr}, \mathrm{Cd}, \mathrm{Mn}, \mathrm{Pb}$ and $\mathrm{As}$ were not detected in the studied area. Higher concentrations of $\mathrm{Zn}$ in very few samples have been observed.

\section{Acknowledgement}

One of the author (Surendra Kumar Sharma) is thankful to the Principal Jain Subodh PG college for providing the necessary laboratory facilities and also thankful to Dr. Vinay Bhardwaj (Sr. Hydro geologist) and Dr. K. C. Sharma Ground water Department, Govt. of Rajasthan, Jaipur for giving their valuable suggestion and possible laboratory facilities.

\section{References}

Adak, M.D. and Purohit K.M. 2001. Status of Surface and Ground Water Quality of Mandiakudar - Part-III: Correlation Coefficient and Regression equations. Poll.Res. 20 (2) : 227 - 232.

Almeida, C., Quintar, S., González, P., Mallea, M., 2008. Assessment of irrigation water quality. A proposal of a quality profile. 142(1-3):149-52

APHA, AWWA, WPCF, Washington, D.C., 1989. Standard Methods for the Examination of Water and Waste Water, edited by Lenore S. Clesceri, $17^{\text {th }}$ edition

Berkowitz., B., Dror. I., Yaron, B., 2008. Contaminant geochemistry: interactions and transport in the subsurface Environment. Springer, Heidelberg. ISBN: 9783540743811.

Bruvold W.H., 1967. "Consumer Attitudes Towards Minerals Taste in Domestic Water", J. American Water Works Association, 59: 89-94.

Collection and Preservation of Samples: Approved by Std. Methods Committee (1994).

Cunningham William P., and Saigo Barbara Woodworth, Environmental Science, McGraw Hill Book Publishing House, New York (1999).

Dalton, M.G., and Upchurch, S.B., 1978, Interpretation of hydro-chemical facies by factor analysis: Groundwater, 16(4): 228-233.

Dar M. A., Sankar K., 2011. Major ion chemistry and hydrochemical studies of groundwater of parts of Palar river basin,Tamil Nadu, IndiaEnviron Monit Assess 176:621-636

Dixit, S., and Tiwari, S., 2008. Impact Assessment of Heavy Metal Pollution of Shahpura Lake, Bhopal, India. International Journal of Environmental Research, 2 (1): 37 - 42.

Guidelines for Drinking Water Quality, 1997. Surveillance and Control of Community Supply, Geneva Vol 3.

Guidelines for Drinking Water Quality", Vol. II, Health Criteria and Other Supporting Information, World Health Organization, Geneva (1996).

Kudesia V.P. and KudesiaRitu, "Water Pollution", PragatiPrakashan, Meerut (1998).

\section{How to cite this article:}

Surendra Kumar Sharma, Richa Sharma, Manisha Mathur and Chandel, C.P.S. 2016. Ground Water Quality Assessment of Ramgarh Mod in Jaipur City, India. Int.J.Curr.Microbiol.App.Sci. 5(10): 166-173. doi: http://dx.doi.org/10.20546/ijcmas.2016.510.019 